\title{
Harnessing Local Immunity for an Effective Universal Swine Influenza Vaccine
}

\author{
Elma Tchilian * and Barbara Holzer \\ The Pirbright Institute, Woking, Surrey GU24 0NF, UK; barbara.holzer@pirbright.ac.uk \\ * Correspondence: elma.tchilian@pirbright.ac.uk \\ Academic Editor: Eric O. Freed \\ Received: 20 March 2017; Accepted: 28 April 2017; Published: 5 May 2017
}

\begin{abstract}
Influenza A virus infections are a global health threat to humans and are endemic in pigs, contributing to decreased weight gain and suboptimal reproductive performance. Pigs are also a source of new viruses of mixed swine, avian, and human origin, potentially capable of initiating human pandemics. Current inactivated vaccines induce neutralising antibody against the immunising strain but rapid escape occurs through antigenic drift of the surface glycoproteins. However, it is known that prior infection provides a degree of cross-protective immunity mediated by cellular immune mechanisms directed at the more conserved internal viral proteins. Here we review new data that emphasises the importance of local immunity in cross-protection and the role of the recently defined tissue-resident memory T cells, as well as locally-produced, and sometimes cross-reactive, antibody. Optimal induction of local immunity may require aerosol delivery of live vaccines, but it remains unclear how long protective local immunity persists. Nevertheless, a universal vaccine might be extremely useful for disease prevention in the face of a pandemic. As a natural host for influenza A viruses, pigs are both a target for a universal vaccine and an excellent model for developing human influenza vaccines.
\end{abstract}

Keywords: Swine influenza; local lung immunity; lung tissue resident memory T cells; universal influenza vaccines; heterosubtypic immunity

\section{Introduction}

Influenza A virus infection is a global health threat to livestock and humans, causing substantial mortality and morbidity. H1N1 and H3N2 influenza viruses are endemic in pigs and humans in addition to H1N2 in pigs. Since human origin viruses, or viruses containing human origin gene segments, frequently adapt to transmit efficiently in pigs [1,2], the pig is a source of new viruses capable of initiating epidemics or pandemics in humans of mixed swine, human, and avian origin [3]. As both pigs and humans are readily infected with influenza A viruses of similar subtype, the pig is a robust and appropriate model for investigating both swine and human disease. Like humans, pigs are outbred, and physiologically, anatomically, and immunologically similar to humans. The porcine lung also resembles the human in terms of its tracheobronchial tree structure, lung physiology, morphology, and distribution of receptors bound by influenza viruses [4,5].

Swine influenza virus (SI) infection exhibits a spectrum of clinical signs, ranging from inapparent disease to fever, with overt respiratory signs and disease severity is increased significantly by secondary bacterial infection. SI contributes to sub-optimal reproductive performance and is occasionally associated with fever-induced abortion in sows. Immunisation may be a cost effective control measure to combat SI, but the rapid evolution of the virus is a major obstacle SI diversity is reviewed in $[1,6,7]$. Not all countries with SI use vaccines to control disease. Current UK policy does not involve immunisation against SI, although it is used in some European countries and widely in the US. While 
it will be difficult to convince government and livestock keepers to invest in control measures for a disease causing insidious losses without providing clear economic and welfare benefits, with pig production intensifying worldwide it is likely that an improved immunisation strategy for SI would result in more countries relying on vaccines to control disease.

Parenterally-administered inactivated vaccines against SI, widely used in the US, are strain-specific and protection correlates with the presence of neutralising antibodies. The most commonly used are whole inactivated virus (WIV) administered with oil-in-water adjuvants, non-replicating alphavirus RNA particle, or autogenous vaccines. For autogenous vaccines the vaccine organism(s) must come from the herd in which the vaccine is to be used, and they accounted for more than half of all SI vaccine doses released for sale in 2008. Recent reviews by Sandbulte et al. [8] and Vincent et al. [6] provide comprehensive information on currently used vaccines in the field in the US. In Europe, RESPIPORC FLU 3 (IDT Biologika, Dessau-Rasslau, Germany) and Gripovac (Merial, Lyon, France) against H1N1, H1N2, and H3N2 circulating SI viruses are used in approximately 5-25\% of the pig farms in Belgium, Denmark, France, Spain, Italy, Poland, and Germany.

However, these vaccines do not protect against new viral strains and show poor efficacy in the field because of the evolution of the virus [9]. This lack of efficacy against mismatched strains has two consequences: (1) it requires frequent reformulation and production of influenza vaccines based on the prediction of strains that may circulate. While virological surveillance for human influenza A and $\mathrm{B}$ viruses is the cornerstone of the World Health Organisation vaccine selection process, a similar strategy for pig (and other) animal influenza vaccines is still lacking; and (2) in the event of the emergence of a completely novel reassortant virus, there is little or no efficacy leaving both swine and humans at high risk of infection with potential for pandemic spread. A further problem of WIV with oil-in-water adjuvants is enhanced respiratory disease and increased pathology, associated with immune complexes of low avidity or non-neutralising antibodies. Vaccine-associated enhanced respiratory disease (VAERD) has been observed in pigs when heterologous SI infection occurs after immunisation with mismatched WIV [10-13]. WIVs are also commonly used in pregnant sows to prevent SI infection in piglets [14]. In these circumstances, maternally derived antibodies can be detected in piglets up to 14 weeks after birth and levels correlate with protection against homologous infections [12]. However, after heterologous challenge WIV induced maternally-derived antibodies were associated with enhanced clinical signs [15].

\section{Universal Influenza Vaccine/Heterotypic Immunity}

A cross-protective "universal vaccine" would be an enormous advantage in preventing SI in pigs and reducing the zoonotic threat. The development of a "universal" or broadly protective influenza A vaccine depends on inducing immune responses to conserved components of the virus that either prevent infection or limit replication of virus after infection has occurred. The classical broad immunity detected in convalescent animals and humans is dominated by the latter, mediated by cross-reactive CD4 and CD8 T lymphocytes [16]. The phenomenon was first observed after the isolation of human influenza in the 1930s when ferrets that had recovered from swine influenza were immune to the human virus but did not make detectable cross-neutralising antibodies $[17,18]$. The term "partial heterotypic immunity" (also called "heterosubtypic") was introduced by Schulman and Kilbourne in 1965 who observed that mice infected with a H1N1 strain and subsequently challenged with a lethal H2N2 virus, had reduced viral titers in the lung, milder lung pathology, and decreased mortality in the absence of neutralizing antibodies [18]. Since then, studies in multiple animal models including non-human primates have observed reduction in viral load, lung pathology, weight loss and decreased mortality, but not infection, in the absence of detectable cross-neutralizing antibodies (reviewed in $[19,20]$ ).

Experimental infection and recovery from SI infection in pigs has also been shown to completely or partially protect against infection with another type of SI [21-24]. Post-infection immunity to H1N1 and/or H3N2 viruses conferred cross protection against H1N2 in pigs [23], in the absence of detectable haemagglutination inhibition and virus neutralising antibodies, although inhibitory anti-neuraminidase 
(NA) antibodies were detected prior to infection with H1N2. In contrast a double vaccination with an inactivated H1N1 and H3N2 based vaccine did not confer significant cross-protection [25], highlighting the importance of active virus replication for the induction of heterosubtypic immunity in pigs, directed towards the conserved internal proteins [26]. In line with these findings partial protection was observed in pigs with infection-induced immunity against avian-like H1N1 upon challenge with $\mathrm{H} 3 \mathrm{~N} 2$, whereas pandemic (pdm)H1N1-immune pigs were not protected because the pdmH1N1 has a different set of internal genes from the challenge strain [22]. In another study pigs previously infected with H1N1, and subsequently challenged with H3N2, did not get fever, showed reduced virus shedding, and showed no transmission to contact pigs [21]. The observed heterosubtypic protection occurred in the absence of cross-reactive haemagglutination inhibition antibodies after primary infection, but correlated with increased serum immunoglobulins (Ig)G antibody levels against the conserved extracellular domain of matrix protein 2 (M2) and nasal nucleoprotein (NP)-specific IgA antibodies. In addition, increased numbers of CD8 $\mathrm{T}$ cells were observed in the lungs of pigs previously infected with $\mathrm{H} 1 \mathrm{~N} 1$ and challenged with H3N2. The extent of heterosubtypic protection varies greatly between studies partly because of the immunisation/challenge strategies used, as well as the degree of conservation of the internal genes between the strains used for immunisation and challenge.

In this review we shall discuss the importance of local lung immunity and the feasibility of making an effective SI universal vaccine.

\section{Respiratory Tract Immunisation}

For optimum induction of heterotypic immunity in experimental animals, virus infection of the lung is required, as opposed to infection of the upper respiratory tract or other peripheral sites $[27,28]$. Immunisation via the respiratory tract has been shown to be a highly effective means of immunising against influenza. A recent murine study that evaluated the capacity of inactivated influenza vaccine or live attenuated influenza vaccine (LAIV) to induce protective lung response showed that site specific productive infection is required. Interestingly intra-nasal administration of inactivated vaccine or parenteral administration of LAIV failed to elicit protective $\mathrm{T}$ cell responses, confirming the requirement for respiratory targeting of LAIV to establish cross-protection [29]. Experimentally, immunisation via the respiratory tract is also highly protective against several other pulmonary diseases in livestock, including bovine tuberculosis [30,31], respiratory syncytial virus in cattle [32] and porcine reproductive and respiratory syndrome virus [33].

Although it is clear that local mucosal immunity is critical for protection against respiratory tract diseases in most cases it is not known what part of the respiratory tract should be targeted to induce optimal protection. Even in non-human primates and humans, where a common respiratory mucosal system has been postulated [34,35], so that immunisation of any part of the respiratory tract might be expected to protect the whole tract, it is not clear whether immunisation of the upper (URT) or lower respiratory tract (LRT) is more effective. A number of studies in mice and ferrets with influenza vaccines show that the LRT is the best target for inhaled influenza vaccination [36,37]. Targeting the LRT and URT by inhalation with the candidate universal influenza vaccine S-FLU (a non-replicating, pseudotyped influenza virus where the viral RNA (vRNA) encoding the haemagglutinin (HA) was inactivated by suppression of the HA signal sequence) resulted in a high degree of cross-protection against $\mathrm{H} 1$ and $\mathrm{H} 3$ influenza strains in mice [38]. This confirms the studies of Lau et al. [27] showing that protection of mice from H5N1 influenza by LAIV requires delivery of vaccine to the lung as opposed to the URT alone. Neutralising Ab were not induced by S-FLU immunisation of mice, ferrets, or pigs [38-40], but strong local lung cellular immune responses were detected, which correlated with protection against challenge. S-FLU coated with $\mathrm{H} 1$ or $\mathrm{H} 5 \mathrm{HA}$ has also been administered to pigs to the LRT by aerosol or intra-tracheal methods [40]. The aerosol method was the most efficient in reducing virus titre in nasal swabs and lung tissue after live virus challenge with pandemic H1N1 virus in pigs [40]. Similar comparisons between intra-tracheal and aerosol delivery have been performed with 
adenoviral vectored TB [30] or Ebola vaccines [41] in non-human primates and, in both cases, aerosol delivery offered superior protection compared to other mucosal routes.

\section{Live Attenuated Influenza Vaccines}

Currently, cold-adapted LAIVs administered by nasal spray, targeting the URT, have been approved for equine (FluAvert, MSD Animal Health, Milton Keynes, UK) and human species (FluMist/Fluenz, MedImmune Gaithersburg, MD, Maryland, US). Studies in young children suggest that LAIV is more protective than inactivated influenza vaccines in those not previously exposed to influenza or influenza vaccines, due to increased vaccine-induced $\mathrm{T}$ cell and/or secretory $\operatorname{IgA}$ responses. In adults with extensive and partially cross-reactive pre-existing influenza immunity, LAIV boosting of secretory IgA reactive with $\mathrm{HA}$ and non-HA antigenic targets expressed by circulating influenza strains, may be an important additional mechanism of vaccine-induced immunity [42]. FluMist was introduced for infants in the UK in 2013, although because of troubling results of recent effectiveness studies, it will not be used during the 2016-2017 vaccination season in the US. The reason for the apparent decreased effectiveness of LAIV as compared with the efficacy shown in the original studies is unclear [43], but it could be related to repeated immunisations and increased baseline immunity, which might interfere with vaccine-virus replication [44].

Experimental LAIV vaccines delivered by the intranasal route have been shown to be protective in pigs [45-48]. Eight segment SI virus harbouring two different HA (H1 and H3) was generated by replacement of the ectodomain of the NA with the ectodomain of a second HA (H3), thus creating a virus displaying two different $\mathrm{HAs}(\mathrm{H} 1$ and $\mathrm{H} 3)$ on the surface [49]. The resulting vaccine was attenuated in pigs and conferred reduction of fever and other clinical signs as well as decreasing gross lesions in the lungs after challenge with both $\mathrm{H} 1$ and $\mathrm{H} 3 \mathrm{SI}$ viruses. LAIVs carrying an elastase cleavage site [50,51], NS1 truncations [24], or temperature-sensitive mutations in the polymerase basic protein (PB) 2 and PB1 segments [45,47] all provide degrees of cross-protection after challenge with antigenically distinct viruses but from the same subtype. Sterilizing immunity with no transmission to naïve pigs, was achieved with the temperature sensitive LAIV as opposed to the NS1 truncated LAIV where transmission was not prevented [45]. Considerably high IgA antibody responses in nasal washes and bronchoalveolar lavage (BAL) against whole virus were found in LAIV-immunised pigs compared to inactivated vaccine groups. The elevated IgA levels alone did not determine sterilizing immunity as both tested LAIV vaccines induced equal titers, but only one prevented transmission, suggesting additional requirements for protection, such as induction of cell-mediated immunity [45]. Partial heterosubtypic protection with the LAIV vaccine carrying the elastase cleavage site was observed when the vaccine was administered in a prime/boost regime and challenged either intratracheally [50] or intranasally [46]. As in other studies with LAIV vaccines, cross reactive IgG in serum and IgA in BAL and nasal mucosa were detected. IFN $\gamma$ secretion by lymph node cells could be induced by exposure to the heterologous challenge strain, suggesting that cell-mediated immunity was also involved in the cross protective effect. Similarly, in NS-1-truncated LAIV immunised animals, heterosubtypic $T$ cell priming against the challenge strain was observed [24], however immune responses waned at 7-8 weeks post immunisation and recall responses of LAIV-immunised pigs were in general lower when compared to wild type-infected pigs or not different from naïve pigs. These results suggest that although LAIV offer partial cross-protection it is less efficient than infection with a live virus.

Clearly the route of delivery is very important for induction of local immunity. Intranasal delivery of a LAIV vaccine was more efficient in inducing mucosal antibodies when compared to intramuscular delivery [48]. It may also be that intra-nasal delivery in pigs is effective because a small proportion of the administered dose reaches some of the lung lobes, albeit most of the material delivered intra-nasally is deposited in the stomach and oesophagus [52]. Whether LAIVs will have much enhanced protective efficacy if deliberately delivered to the LRT requires thorough investigation to determine whether this is more efficient in inducing both homologous and heterologous protection against SI in pigs. However, despite major advances in aerosol vaccine delivery in humans [53] and some examples of 
local delivery to livestock, no practical devices for aerosol delivery are yet available for farm animals in the field.

\section{Safety and Danger of Re-Assortment of LAIV}

LAIV given as a large droplet aerosol to the URT in humans still requires updating to keep pace with antigenic drift, implying that type specific antibody is the main mechanism of protection. By contrast when administered to the LRT in mice and ferrets it can act as a "universal" influenza vaccine by inducing a multi-component response that is cross-protective between group I (H5N1) and group 2 (H7N9) influenza viruses [39,54]. However, administration of LAIV by small droplet aerosol to the lung in humans (or other species) is strongly discouraged by the manufacturer [55], due to concerns that replication is not completely restricted at $37^{\circ} \mathrm{C}$. In addition pre-pandemic versions of LAIV contain full length versions of vRNAs encoding potentially pandemic HAs, which could reassort into seasonal influenza viruses in cases of dual infection. Similarly reassortment of LAIVs with wild-type swine strains is possible. Furthermore, mixing of different vaccines from different sources is common in the field and if two LAIV vaccines were to be mixed prior to administration to pigs, there is a chance that a wild type SI will be generated with gene segments derived from unmodified gene segments in each LAIV vaccine. This might lead to even more diversity of swine IAV strains or strains with increased zoonotic potential [6].

The universal vaccine candidate, S-FLU was designed to overcome these objections. It is based on the suppression of HA signal sequence, most of the coding sequence of the HA viral RNA is deleted. HA protein is provided from a transfected cell line by pseudotyping. This design allows infection by S-FLU to occur once only and replication of vaccine in the lung or nose is prevented, but all of the conserved viral proteins are expressed in the cytosol of S-FLU infected cells and available for antigen presentation to T lymphocytes [56]. S-FLU cannot replicate in the lung due to lack of a viable HA vRNA, and cannot donate a viable vRNA encoding HA because it does not contain any genetic information from the potentially pandemic virus, being only coated in HA protein. Another single-replication cycle universal vaccine candidate RedeeFlu (FluGen Inc, Madison, WI, USA) is based on the partial deletion of the M2 gene [57] and shown to elicit humoral, mucosal, and cell mediated immunity. The vaccine induced sterilising immunity to homosubtypic challenge, but although it protected mice against lethal heterosubtypic challenge it did not prevent viral replication in nasal turbinates and lung.

\section{Immunological Mechanisms of Heterotypic Protection}

Investigation of the immunological mechanisms mediating the cross protective heterotypic immunity in animal models revealed the role of CD8 and CD4 T-cells and has been reviewed in [20]. The specificity of the protective effect correlates with the conserved viral core antigens recognised by T cells $[16,58,59]$ and protection can be transferred in mice with core protein-specific T cells, particularly class I restricted cytotoxic T lymphocytes [60,61]. A recent prospective study in humans also showed this correlation between cross-reactive CD8 T cell responses and protection from symptomatic infection during the H1N1 influenza pandemic $[62,63]$, confirming earlier work from experimental challenges with influenza virus in humans $[59,64]$.

Similar CD8 systemic responses against the internal NP and M proteins were induced in both pigs and humans after intra-muscular immunisation with a candidate universal Modified Vaccinia Ankara vaccine encoding NP and M1 proteins [65]. This vaccine has been tested in co-administration regimes with either HA protein or following prime boost with a chimpanzee adeno vector also expressing NP and M1 and was shown to induce T cell responses to NP and M1 in pigs. However, no challenge was performed. Whether CD8 cells induced by parenteral immunisation would have the same protective effect as CD8 cells induced by local pulmonary infection or immunisation remains to be established, although there are ongoing efforts to induce mucosal responses through systemic parenteral immunisation in other diseases $[66,67]$. Alternatively harnessing simultaneously both local 
and systemic immunity might be an optimal strategy as immunisation against tuberculosis in mice and non-human primates has demonstrated $[68,69]$.

However, despite the wealth of evidence for both CD4 and CD8 T cell mediated cross-protection in mice and humans, studies in pigs are very scarce. An immunoinformatic tool for predicting swine $\mathrm{T}$ cell epitopes identified highly conserved class I and class II epitopes among seven SI strains prevalent in US pig herds. The class I peptides were restricted to the external proteins, while responses to class II peptides were focused on epitopes derived from the internal proteins [70]. This is in contrast to humans in whom most cross-reactive CD8 and CD4 T cell epitopes are derived from internal influenza virus proteins. SI class I epitopes were also identified and tetramers developed in pigs following four repeated immunisations with different SI strains in incomplete Freund's adjuvant [71]. Further studies will be needed to evaluate whether epitope based vaccines will be able to reduce viral burden and morbidity.

The only studies analysing local and systemic immune responses following infection with SI by the pulmonary route, albeit intra-tracheal infection with high dose H1N2, revealed multifunctional $\mathrm{T}$ cells with diverse cytokine profiles and in vitro reactivity against heterologous influenza strains, supporting their potential to combat heterologous influenza virus infections in pigs [72,73]. Low frequency SI specific IFN $\gamma$ producing CD4 and CD8 cells were detected in the lungs four days post-infection, reaching a peak at nine days post infection. At six weeks post-infection CD4 and CD8 memory T cells had accumulated in the lung tissues, but it is not known which epitopes these cells are targeting. Neither is it known whether natural infection induces cells which recognise the informatically defined epitopes.

\section{Tissue-Resident Memory T Cells}

$\mathrm{T}$ cell memory was previously considered to be mediated by recirculating memory cells able to pass from the blood to tissues and back to the blood via the lymph. It was not thought that the cells remained in tissues for more than few hours, nor that they divide in non-lymphoid tissues. However recent overwhelming evidence indicates the importance of local tissue-resident memory $\mathrm{T}$ cells $\left(\mathrm{T}_{\mathrm{RM}}\right)$ in protective immunity. $\mathrm{T}_{\mathrm{RM}}$ are a newly-defined subset of memory $\mathrm{T}$ cells generated following primary infection in tissues such as the respiratory tract, gastrointestinal tract and skin and they persist at these sites after the pathogen has been cleared by the immune response $[74,75]$. Upon subsequent infection, pathogen-specific $\mathrm{T}_{\mathrm{RM}}$ cells mount a rapid local response that is independent of $\mathrm{T}$ cell recruitment from the blood. Surprisingly, sessile $\mathrm{T}_{\mathrm{RM}}$ greatly outnumber recirculating $\mathrm{T}$ cells within non-lymphoid tissues [76]. They express homing molecules such as the integrin CD103 and the activation marker CD69, the latter indicating that these cells are dividing and likely express effector function. However, there is some phenotypic heterogeneity and overlap of phenotype with cells in blood and lymphoid tissues, so that $\mathrm{T}_{\mathrm{RM}}$ are best defined by their inaccessibility from the blood stream. This has been elegantly demonstrated by the intravenous administration of labelled antibody, which identifies all intra-vascular, but not tissue-resident cells [76] and by experiments which prevent efflux of cells from lymph nodes so that recirculating cells cannot reach the tissues $[77,78]$.

It is increasingly evident that lung $\mathrm{T}_{\mathrm{RM}}$ play a major role in protective immunity against respiratory tract infections. In mice both $\mathrm{CD} 4$ and $\mathrm{CD} 8$ lung $\mathrm{T}_{\mathrm{RM}}$, induced by immunisation via the respiratory tract, mediate immunity against heterosubtypic influenza strains, enhancing viral clearance and survival after lethal challenge $[29,77,79,80]$. Influenza-specific $T_{R M}$ are also present in most healthy humans [81,82]. After pneumonectomy for isolated tumours, histologically normal human lung tissue far from the tumours contains both CD4 and CD8 cells with diverse T cell receptors (TCR) that express $\mathrm{CD} 69$, produce TNF $\alpha$ and IFN $\gamma$ and proliferate in response to influenza virus. $\mathrm{T}_{\mathrm{RM}}$ were also found in a large survey of human tissues [83] and in BAL after respiratory syncytial virus infection [84].

The effector functions of $\mathrm{T}_{\mathrm{RM}}$ remain incompletely understood, but may involve: (1) direct killing of pathogen-infected cells; (2) release of cytokines that render the surrounding environment non-permissive for pathogen replication; and (3) promoting recruitment of infection-fighting cells 
from the circulation [75]. The only studies on the duration of cross reactive immunity mediated by $\mathrm{T}_{\mathrm{RM}}$ have been performed in mice and have shown that heterosubtypic immunity was substantially reduced after seven months [77].

The few studies that have investigated how $\mathrm{T}_{\mathrm{RM}}$ cells are induced and maintained have used mouse models. Factors necessary for the induction of $\mathrm{T}_{\mathrm{RM}}$ are not currently well understood but both the route of antigen encounter and the nature of the antigen itself may play a crucial role [29]. However, despite these advances in mice and although $\mathrm{T}_{\mathrm{RM}}$ cells have been identified in the human lung, we currently understand very little about the role of $\mathrm{T}_{\mathrm{RM}}$ in any other species, how they are generated in response to infection or vaccination, or how best to induce them. There is no information on $\mathrm{T}_{\mathrm{RM}}$ in pigs or other livestock, but it is to be expected that they play an important role in protection against SI in these species.

\section{Mucosal Associated Invariant T Cells}

Although conventional T cells are clearly important, the mucosal immune system contains other cell populations whose functions are less clear. One such population is the recently discovered mucosal associated invariant T cells (MAITs), which exhibit properties of both innate and adaptive cells, as do natural killer $\mathrm{T}$ cells and gamma delta $\mathrm{T}$ cells (reviewed in [85-87]). They are highly enriched in mucosal sites, including lungs, intestines and liver, but are also present in the periphery where they can make up between $1-10 \%$ of the total circulating lymphocytes. In humans, MAITs express the Va7.2-Ja33 chain of the T cell receptor, make up to $~ 10 \%$ of blood CD8 cells and detect riboflavin metabolites bound to the non-polymorphic major histocompatibility complex (MHC) class-I related protein, MR1.

MAITs are associated with protection from bacterial infections, but recently were shown to be activated by influenza virus through mechanisms independent of MR1-TCR engagement and mediated through IL-18 combined with IL-12, IL-15, and/or interferon- $\alpha / \beta$, which are expressed by a range of antigen presenting cells and monocytes [88]. The importance of MAITs in influenza is suggested by the correlation of patient survival with a $~ 2.5$ fold increase in total MAITs cell numbers. Here too, MAIT activation was highly dependent on secondary cytokine stimulation derived from monocytes and activation is primarily, but not entirely, IL18-dependent [89]. MAITs have been identified in sheep and cattle, but there is no published data on pigs, nor has the role of MAITs in SI been defined.

\section{Antibody Mediated Cross-Protective Immunity}

Protective humoral responses to influenza are usually associated with antibodies against its surface glycoproteins HA and NA and in the last decade many laboratories identified broadly cross-protective antibodies directed against the highly-conserved HA stalk domain that showed different levels of cross-reactivity towards group 1 [90-92], group 2 [93-95] or both group 1 and 2 viruses [96-99]. Multiple studies have shown that in vivo efficacy of broadly cross neutralising anti-stalk antibodies is dependent on Fc-dependent mechanisms, like antibody-dependent cytotoxicity, antibody-dependent cellular phagocytosis, and complement-dependent cytotoxicity. A problem related to the development of anti-stem antibodies is their variable neutralising potency against viruses belonging to different subtypes and the existence of natural escape mutants, although some exhibit unprecedented breadth and potency [100]. Vaccine strategies targeting antibodies to the conserved stalk region of HA involve "headless" HA although responses were suboptimal, probably because removal of the head domain destroyed important conformational epitopes, or destabilized the stem domain in such a way that it was no longer able to elicit protective antibody responses. An alternative approach uses a vaccine consisting of a chimeric HA structure made of the conserved HA stem domain of an $\mathrm{H} 1$ or $\mathrm{H} 3$ strain of influenza, capped with the HA head domain from an exotic zoonotic influenza strain that has not been previously encountered by the human population, most likely directing the recall responses to stimulate pre-existing stem-reactive memory B cells (reviewed in [101,102]). 
A recent mouse study suggests that memory B cells specific for broadly neutralizing epitopes may reside in the lungs instead of in circulation or in secondary lymphoid organs. These lung-resident memory B cells were highly mutated, and were generated as a result of local persistent germinal centres that are responding to prolonged exposure to viral antigens found in the lung. These tissue-resident memory B cells provided robust protection against a drifted virus in a secondary challenge model, confirming their importance in generating a cross-reactive, broadly neutralizing antibody response against influenza [103]. Although these findings have not yet been confirmed in humans or livestock, it does suggest a role for tissue-resident memory B cells in providing broadly-neutralizing responses.

IgA has been implicated in host protection against influenza in several studies [104,105]. Polymeric forms of IgA in nasal washes from adults vaccinated intranasally with a WIV are very potent in neutralizing influenza virus [106]. Interestingly IgA can also intercept antigen within epithelial cells [107] and for example, in that way NP-specific IgA in the nasal mucosa in pigs after SI infection may contribute to virus clearance [21]. HA-specific IgA antibody responses in the nasal washes have been detected as early as four days after intranasal or intratracheal inoculation with SI in $50 \%$ of pigs [108]. Cells isolated from the nasal turbinates and lymphoid tissue of the soft palate were tested for their ability to secrete influenza virus-specific IgA or IgG [109]. Notably those cells produced IgA, whereas significantly less cells produced IgG. Most likely IgA-producing cells can also be isolated in pigs from the lungs as high titres of IgA were found in the BAL fluid. In mice protection from influenza correlated with influenza-specific $\operatorname{IgA}$ and $\operatorname{IgG}$ antibody secreting cells in the lung at the time of challenge [110]. Therefore, it is quite likely that a major contributor to the protective efficacy of LAIV vaccine is IgA produced in the local mucosa.

Recently the breadth and magnitude of $\mathrm{Ab}$ response directed against HA and NA has been determined in mice, guinea pigs and ferrets following sequential infections with H1N1 or H3N2 influenza viruses [111]. Guinea pigs developed high titres of broadly cross-reactive antibodies, while mice and ferrets exhibited narrower responses. When these were compared to the antibody responses after infection of humans with $\mathrm{H} 1 \mathrm{~N} 1$ or H3N2 a markedly broad response was found, with the cross-reactivity profiles dependent on the viral strain first encountered during childhood (original antigenic sin). Re-analysis of the Cleveland Family Study which monitored families before and during the pandemic of 1957 where a subtype shift from H1N1 to H2N2 occurred, did show significantly lower incident rates during the pandemic in adults that contracted symptomatic influenza before, compared to children [112]. Recently it was shown that childhood hemagglutinin imprinting conferred lifelong protection against severe infection and death from novel HA as long as the virus belonged to the same phylogenetic group as the one encountered first in an individual's life [113]. Better understanding of cross-reactive immunity in humans is important for the development of universal vaccine strategies that are designed to boost pre-existing antibodies to protective levels. However, there is surprising lack of information about the landscape of the antibody response in pigs, which are exposed to multiple SI and very often are infected with one or more different SI subtypes without overt disease, a situation that may reflect better the immune responses in humans with pre-existing immunity and a complicated history of exposure to influenza viruses.

However, the role of antibodies in protection needs further evaluation and caution, because of some evidence for enhancement of disease by antibody. VAERD was associated with the presence of high titre cross-reacting non-neutralizing antibodies targeting the conserved stem HA2 domain at a site adjacent to the fusion peptide. In the absence of neutralizing antibodies against the HA1 globular head of pdmH1N1, HA2 antibodies increased virus infection of MDCK cells in vitro and enhanced membrane fusion [114]. However, VAERD is mainly associated with WIV administered with oil-in-water adjuvant parenterally, and has not been reported after LAIV administration by the mucosal route [115]. Although an immune response against mismatched HA protein alone was enough to cause VAERD [116], it has been shown recently that NA inhibiting antibodies to the homologous NA were sufficient to abrogate it [117]. There clearly is a need to determine the relative contribution of all types of anti-influenza antibodies, rather than focusing only on those to the HA stem. 


\section{Conclusions}

The global influenza community is in urgent need of a universal influenza vaccine capable of inducing durable cross-protection against a broad spectrum of influenza virus strains. Harnessing local T cell immunity is essential for the development of a practical and effective universal influenza vaccine. Vaccines that induce $\mathrm{T}$ cell mediated immunity reduce disease severity and may reduce or prevent transmission, but do not prevent infection. The evaluation, licensure and deployment of a vaccine not designed to prevent infection, but to limit the severity of disease, will be challenging, as it must show comparable or better efficacy than current vaccines. However, universal vaccines might substantially reduce the severity of infection and limit the spread of disease during outbreaks and could be used 'off the shelf' early in an outbreak or pandemic, before strain-matched vaccines are available. In contrast a universal vaccine based on antibody responses would prevent infection and broadly-neutralizing antibodies specific for the conserved stem domain of the HA have shown promise both from a therapeutic perspective, as well as for guiding vaccine design efforts. Since most studies of human broadly-neutralizing monoclonal antibodies have focused primarily on B cells isolated from blood samples, a focus on lung-resident memory B cells may provide greater insight into how to generate broadly neutralizing antibodies. Future delivery strategies must consider how to best boost lung-resident memory B cells to elicit potent broadly protective responses. Combining both approaches would be a viable strategy and only field trials will show whether a universal vaccine could induce sufficient herd immunity to be useful. It is important to be aware of the limitations of the animal models used to study universal vaccines. It is challenging to scale up from $25 \mathrm{~g}$ mice to $70 \mathrm{~kg}$ humans. Pigs of 10 to $60 \mathrm{~kg}$ approach the weight of humans and, therefore, have great potential as a translation tool for therapeutics, such as antibodies and vaccines. Swine are also natural hosts of influenza viruses and play a critical role in the emergence and epidemiology of novel and potentially zoonotic influenza viruses. They are, therefore, a powerful model to study immunity to influenza.

Conflicts of Interest: The authors disclose no conflict of interest.

\section{References}

1. Watson, S.J.; Langat, P.; Reid, S.M.; Lam, T.T.; Cotten, M.; Kelly, M.; Van Reeth, K.; Qiu, Y.; Simon, G.; Bonin, E.; et al. Molecular epidemiology and evolution of influenza viruses circulating within European swine between 2009 and 2013. J. Virol. 2015, 89, 9920-9931. [CrossRef] [PubMed]

2. Nelson, M.I.; Vincent, A.L. Reverse zoonosis of influenza to swine: New perspectives on the human-animal interface. Trends Microbiol. 2015, 23, 142-153. [CrossRef] [PubMed]

3. Smith, G.J.D.; Vijaykrishna, D.; Bahl, J.; Lycett, S.J.; Worobey, M.; Pybus, O.G.; Ma, S.K.; Cheung, C.L.; Raghwani, J.; Bhatt, S.; et al. Origins and evolutionary genomics of the 2009 swine-origin H1N1 influenza a epidemic. Nature 2009, 459, 1122-1125. [CrossRef] [PubMed]

4. Rajao, D.S.; Vincent, A.L. Swine as a model for influenza A virus infection and immunity. ILAR J. 2015, 56, 44-52. [CrossRef] [PubMed]

5. Janke, B.H. Influenza A virus infections in swine: Pathogenesis and diagnosis. Vet. Pathol. 2014, 51, 410-426. [CrossRef] [PubMed]

6. Vincent, A.L.; Perez, D.R.; Rajao, D.; Anderson, T.K.; Abente, E.J.; Walia, R.R.; Lewis, N.S. Influenza A virus vaccines for swine. Vet. Microbiol. 2016. [CrossRef] [PubMed]

7. Lewis, N.S.; Russell, C.A. The global antigenic diversity of swine influenza A viruses. Elife 2016, 5, e12217. [CrossRef] [PubMed]

8. Sandbulte, M.R.; Spickler, A.R.; Zaabel, P.K.; Roth, J.A. Optimal use of vaccines for control of influenza A virus in swine. Vaccines 2015, 3, 22-73. [CrossRef] [PubMed]

9. Rahn, J.; Hoffmann, D.; Harder, T.C.; Beer, M. Vaccines against influenza A viruses in poultry and swine: Status and future developments. Vaccine 2015, 33, 2414-2424. [CrossRef] [PubMed]

10. Gauger, P.C.; Vincent, A.L.; Loving, C.L.; Lager, K.M.; Janke, B.H.; Kehrli, M.E.; Roth, J.A. Enhanced pneumonia and disease in pigs vaccinated with an inactivated human-like (delta-cluster) H1N2 vaccine and challenged with pandemic 2009 H1N1 influenza virus. Vaccine 2011, 29, 2712-2719. [CrossRef] [PubMed] 
11. Gauger, P.C.; Vincent, A.L.; Loving, C.L.; Henningson, J.N.; Lager, K.M.; Janke, B.H.; Kehrli, M.E., Jr.; Roth, J.A. Kinetics of lung lesion development and pro-inflammatory cytokine response in pigs with vaccine-associated enhanced respiratory disease induced by challenge with pandemic (2009) A/H1N1 influenza virus. Vet. Pathol. 2012, 49, 900-912. [CrossRef] [PubMed]

12. Kitikoon, P.; Nilubol, D.; Erickson, B.J.; Janke, B.H.; Hoover, T.C.; Sornsen, S.A.; Thacker, E.L. The immune response and maternal antibody interference to a heterologous H1N1 swine influenza virus infection following vaccination. Vet. Immunol. Immunopathol. 2006, 112, 117-128. [CrossRef] [PubMed]

13. Souza, C.K.; Rajao, D.S.; Loving, C.L.; Gauger, P.C.; Perez, D.R. Age at vaccination and timing of infection do not alter vaccine-associated enhanced respiratory disease in influenza a virus-infected pigs. Clin. Vaccine Immunol. 2016, 23, 470-482. [CrossRef] [PubMed]

14. Vincent, A.L.; Ma, W.; Lager, K.M.; Janke, B.H.; Richt, J.A. Swine influenza viruses a north american perspective. Adv. Virus Res. 2008, 72, 127-154. [PubMed]

15. Rajao, D.S.; Sandbulte, M.R.; Gauger, P.C.; Kitikoon, P.; Platt, R.; Roth, J.A.; Perez, D.R.; Loving, C.L.; Vincent, A.L. Heterologous challenge in the presence of maternally-derived antibodies results in vaccine-associated enhanced respiratory disease in weaned piglets. Virology 2016, 491, 79-88. [CrossRef] [PubMed]

16. Doherty, P.C.; Kelso, A. Toward a broadly protective influenza vaccine. J. Clin. Invest. 2008, 118, 3273-3275. [CrossRef] [PubMed]

17. Francis, T.; Shope, R.E. Neutralization tests with sera of convalescent or immunized animals and the viruses of swine and human influenza. J. Exp. Med. 1936, 63, 645-653. [CrossRef] [PubMed]

18. Schulman, J.L.; Kilbourne, E.D. Induction of partial specific heterotypic immunity in mice by a single infection with influenza a virus. J. Bacteriol. 1965, 89, 170-174. [PubMed]

19. Epstein, S.L.; Price, G.E. Cross-protective immunity to influenza A viruses. Expert Rev. Vaccines 2010, 9, 1325-1341. [CrossRef] [PubMed]

20. Sridhar, S. Heterosubtypic T-cell immunity to influenza in humans: Challenges for universal T-cell influenza vaccines. Front. Immunol. 2016, 7, 195. [CrossRef] [PubMed]

21. Heinen, P.P.; de Boer-Luijtze, E.A.; Bianchi, A.T. Respiratory and systemic humoral and cellular immune responses of pigs to a heterosubtypic influenza a virus infection. J. Gen. Virol. 2001, 82, 2697-2707. [CrossRef] [PubMed]

22. Qiu, Y.; De Hert, K.; Van Reeth, K. Cross-protection against european swine influenza viruses in the context of infection immunity against the 2009 pandemic H1N1 virus: Studies in the pig model of influenza. Vet. Res. 2015, 46, 105. [CrossRef] [PubMed]

23. Van Reeth, K.; Gregory, V.; Hay, A.; Pensaert, M. Protection against a european h1n2 swine influenza virus in pigs previously infected with H1N1 and/or H3N2 subtypes. Vaccine 2003, 21, 1375-1381. [CrossRef]

24. Kappes, M.A.; Sandbulte, M.R.; Platt, R.; Wang, C.; Lager, K.M.; Henningson, J.N.; Lorusso, A.; Vincent, A.L.; Loving, C.L.; Roth, J.A.; et al. Vaccination with NS1-truncated H3N2 swine influenza virus primes T cells and confers cross-protection against an H1N1 heterosubtypic challenge in pigs. Vaccine 2012, 30, 280-288. [CrossRef] [PubMed]

25. Van Reeth, K.; Van Gucht, S.; Pensaert, M. Investigations of the efficacy of european H1N1- and H3N2-based swine influenza vaccines against the novel h1n2 subtype. Veterinary Record 2003, 153, 9-13. [CrossRef] [PubMed]

26. Reeth, K.V.; Brown, I.; Essen, S.; Pensaert, M. Genetic relationships, serological cross-reaction and cross-protection between H1N2 and other influenza a virus subtypes endemic in european pigs. Virus Res. 2004, 103, 115-124. [CrossRef] [PubMed]

27. Lau, Y.F.; Wright, A.R.; Subbarao, K. The contribution of systemic and pulmonary immune effectors to vaccine-induced protection from H5N1 influenza virus infection. J. Virol. 2012, 86, 5089-5098. [CrossRef] [PubMed]

28. S, F.d.S.G.; Donnelley, M. Studies in experimental immunology of influenza. Iv. The protective value of active immunization. Aust. J. Exp. Biol. Med. Sci. 1950, 28, 61-75.

29. Zens, K.D.; Chen, J.K.; Farber, D.L. Vaccine-generated lung tissue-resident memory T cells provide heterosubtypic protection to influenza infection. JCI Insight 2016, 1. [CrossRef] [PubMed]

30. Jeyanathan, M.; Shao, Z.; Yu, X.; Harkness, R.; Jiang, R.; Li, J.; Xing, Z.; Zhu, T. Adhu5ag85a respiratory mucosal boost immunization enhances protection against pulmonary tuberculosis in BCG-primed non-human primates. PLoS ONE 2015, 10, e0135009. [CrossRef] [PubMed] 
31. Dean, G.S.; Clifford, D.; Whelan, A.O.; Tchilian, E.Z.; Beverley, P.C.; Salguero, F.J.; Xing, Z.; Vordermeier, H.M.; Villarreal-Ramos, B. Protection induced by simultaneous subcutaneous and endobronchial vaccination with BCG/BCG and BCG/adenovirus expressing antigen 85a against Mycobacterium bovis in cattle. PLoS ONE 2015, 10, e0142270. [CrossRef] [PubMed]

32. Taylor, G.; Thom, M.; Capone, S.; Pierantoni, A.; Guzman, E.; Herbert, R.; Scarselli, E.; Napolitano, F.; Giuliani, A.; Folgori, A.; et al. Efficacy of a virus-vectored vaccine against human and bovine respiratory syncytial virus infections. Sci. Transl. Med. 2015, 7, 300ra127. [CrossRef] [PubMed]

33. Binjawadagi, B.; Dwivedi, V.; Manickam, C.; Ouyang, K.; Torrelles, J.B.; Renukaradhya, G.J. An innovative approach to induce cross-protective immunity against porcine reproductive and respiratory syndrome virus in the lungs of pigs through adjuvanted nanotechnology-based vaccination. Int. J. Nanomed. 2014, 9, 1519-1535.

34. Bourdin, A.; Gras, D.; Vachier, I.; Chanez, P. Upper airway x 1: Allergic rhinitis and asthma: United disease through epithelial cells. Thorax 2009, 64, 999-1004. [CrossRef] [PubMed]

35. Hurst, J.R. Upper airway. 3: Sinonasal involvement in chronic obstructive pulmonary disease. Thorax 2010, 65, 85-90. [CrossRef] [PubMed]

36. Minne, A.; Louahed, J.; Mehauden, S.; Baras, B.; Renauld, J.C.; Vanbever, R. The delivery site of a monovalent influenza vaccine within the respiratory tract impacts on the immune response. Immunology 2007, 122, 316-325. [CrossRef] [PubMed]

37. Song, K.; Bolton, D.L.; Wei, C.J.; Wilson, R.L.; Camp, J.V.; Bao, S.; Mattapallil, J.J.; Herzenberg, L.A.; Herzenberg, L.A.; Andrews, C.A.; et al. Genetic immunization in the lung induces potent local and systemic immune responses. Proc. Natl. Acad. Sci. USA 2010, 107, 22213-22218. [CrossRef] [PubMed]

38. Powell, T.J.; Silk, J.D.; Sharps, J.; Fodor, E.; Townsend, A.R. Pseudotyped influenza A virus as a vaccine for the induction of heterotypic immunity. J. Virol. 2012, 86, 13397-13406. [CrossRef] [PubMed]

39. Baz, M.; Boonnak, K.; Paskel, M.; Santos, C.; Powell, T.; Townsend, A.; Subbarao, K. Nonreplicating influenza a virus vaccines confer broad protection against lethal challenge. MBio 2015, 6, e01487-01415. [CrossRef] [PubMed]

40. Morgan, S.B.; Hemmink, J.D.; Porter, E.; Harley, H.; Holly, H.; Aramouni, M.; Everett, H.E.; Brookes, S.; Bailey, M.; Townsend, A.M.; et al. Aerosol delivery of a candidate universal influenza vaccine reduces viral load in pigs challenged with pandemic H1N1 virus. J. Immunol. 2016, 196, 5014-5023. [CrossRef] [PubMed]

41. Meyer, M.; Garron, T.; Lubaki, N.M.; Mire, C.E.; Fenton, K.A.; Klages, C.; Olinger, G.G.; Geisbert, T.W.; Collins, P.L.; Bukreyev, A. Aerosolized ebola vaccine protects primates and elicits lung-resident $\mathrm{T}$ cell responses. J. Clin. Invest. 2015, 125, 3241-3255. [CrossRef] [PubMed]

42. Hoft, D.F.; Lottenbach, K.R.; Blazevic, A.; Turan, A.; Blevins, T.P.; Pacatte, T.P.; Yu, Y.; Mitchell, M.C.; Hoft, S.G.; Belshe, R.B. Comparisons of the humoral and cellular immune responses induced by live attenuated influenza vaccine and inactivated influenza vaccine in adults. Clin. Vaccine Immunol. 2017, 24. [CrossRef] [PubMed]

43. Belshe, R.B.; Mendelman, P.M.; Treanor, J.; King, J.; Gruber, W.C.; Piedra, P.; Bernstein, D.I.; Hayden, F.G.; Kotloff, K.; Zangwill, K.; et al. The efficacy of live attenuated, cold-adapted, trivalent, intranasal influenzavirus vaccine in children. N. Engl. J. Med. 1998, 338, 1405-1412. [CrossRef] [PubMed]

44. Treanor, J.J. Clinical practice. Influenza vaccination. N. Engl. J. Med. 2016, 375, 1261-1268. [CrossRef] [PubMed]

45. Loving, C.L.; Lager, K.M.; Vincent, A.L.; Brockmeier, S.L.; Gauger, P.C.; Anderson, T.K.; Kitikoon, P.; Perez, D.R.; Kehrli, M.E. Efficacy in pigs of inactivated and live attenuated influenza virus vaccines against infection and transmission of an emerging H3N2 similar to the 2011-2012 H3N2v. J. Virol. 2013, 87, 9895-9903. [CrossRef] [PubMed]

46. Masic, A.; Lu, X.; Li, J.; Mutwiri, G.K.; Babiuk, L.A.; Brown, E.G.; Zhou, Y. Immunogenicity and protective efficacy of an elastase-dependent live attenuated swine influenza virus vaccine administered intranasally in pigs. Vaccine 2010, 28, 7098-7108. [CrossRef] [PubMed]

47. Pena, L.; Vincent, A.L.; Ye, J.; Ciacci-Zanella, J.R.; Angel, M.; Lorusso, A.; Gauger, P.C.; Janke, B.H.; Loving, C.L.; Perez, D.R. Modifications in the polymerase genes of a swine-like triple-reassortant influenza virus to generate live attenuated vaccines against 2009 pandemic H1N1 viruses. J. Virol. 2011, 85, 456-469. [CrossRef] [PubMed] 
48. Vincent, A.L.; Ma, W.; Lager, K.M.; Janke, B.H.; Webby, R.J.; Garcia-Sastre, A.; Richt, J.A. Efficacy of intranasal administration of a truncated ns1 modified live influenza virus vaccine in swine. Vaccine 2007, 25, 7999-8009. [CrossRef] [PubMed]

49. Masic, A.; Pyo, H.M.; Babiuk, S.; Zhou, Y. An eight-segment swine influenza virus harboring h1 and h3 hemagglutinins is attenuated and protective against H1N1 and H3N2 subtypes in pigs. J. Virol. 2013, 87, 10114-10125. [CrossRef] [PubMed]

50. Masic, A.; Booth, J.S.; Mutwiri, G.K.; Babiuk, L.A.; Zhou, Y. Elastase-dependent live attenuated swine influenza A viruses are immunogenic and confer protection against swine influenza A virus infection in pigs. J. Virol. 2009, 83, 10198-10210. [CrossRef] [PubMed]

51. Babiuk, S.; Masic, A.; Graham, J.; Neufeld, J.; van der Loop, M.; Copps, J.; Berhane, Y.; Pasick, J.; Potter, A.; Babiuk, L.A.; et al. An elastase-dependent attenuated heterologous swine influenza virus protects against pandemic H1N1 2009 influenza challenge in swine. Vaccine 2011, 29, 3118-3123. [CrossRef] [PubMed]

52. Hemmink, J.D.; Morgan, S.B.; Aramouni, M.; Everett, H.; Salguero, F..; Canini, L.; Porter, E.; Chase-Topping, M.; Beck, K.; Loughlin, R.M.; et al. Distinct immune responses and virus shedding in pigs following aerosol, intra-nasal and contact infection with pandemic swine influenza a virus, a(H1N1)09. Vet. Res. 2016, 47, 103. [CrossRef] [PubMed]

53. Low, N.; Bavdekar, A.; Jeyaseelan, L.; Hirve, S.; Ramanathan, K.; Andrews, N.J.; Shaikh, N.; Jadi, R.S.; Rajagopal, A.; Brown, K.E.; et al. A randomized, controlled trial of an aerosolized vaccine against measles. N. Engl. J. Med. 2015, 372, 1519-1529. [CrossRef] [PubMed]

54. Tannock, G.A.; Paul, J.A.; Barry, R.D. Relative immunogenicity of the cold-adapted influenza virus a/ann arbor /6/60 (a/aa/6/60-ca), recombinants of a/aa/6/60-ca, and parental strains with similar surface antigens. Infect. Immun. 1984, 43, 457-462. [PubMed]

55. Ambrose, C.S.; Coelingh, K.L. Small-particle aerosolization of live attenuated influenza vaccine virus. J. Infect. Dis. 2012, 205, 348-349. [CrossRef] [PubMed]

56. Townsend, A.R.; Gotch, F.M.; Davey, J. Cytotoxic T cells recognize fragments of the influenza nucleoprotein. Cell 1985, 42, 457-467. [CrossRef]

57. Sarawar, S.; Hatta, Y.; Watanabe, S.; Dias, P.; Neumann, G.; Kawaoka, Y.; Bilsel, P. M2sr, a novel live single replication influenza virus vaccine, provides effective heterosubtypic protection in mice. Vaccine 2016, 34, 5090-5098. [CrossRef] [PubMed]

58. Lee, L.Y.; Ha do, L.A.; Simmons, C.; de Jong, M.D.; Chau, N.V.; Schumacher, R.; Peng, Y.C.; McMichael, A.J.; Farrar, J.J.; Smith, G.L.; et al. Memory t cells established by seasonal human influenza a infection cross-react with avian influenza A (H5N1) in healthy individuals. J. Clin. Invest. 2008, 118, 3478-3490. [CrossRef] [PubMed]

59. Wilkinson, T.M.; Li, C.K.; Chui, C.S.; Huang, A.K.; Perkins, M.; Liebner, J.C.; Lambkin-Williams, R.; Gilbert, A.; Oxford, J.; Nicholas, B.; et al. Preexisting influenza-specific CD4+ t cells correlate with disease protection against influenza challenge in humans. Nat. Med. 2012, 18, 274-280. [CrossRef] [PubMed]

60. Yap, K.L.; Ada, G.L. The recovery of mice from influenza virus infection: Adoptive transfer of immunity with immune T lymphocytes. Scand. J. Immunol. 1978, 7, 389-397. [CrossRef] [PubMed]

61. Taylor, P.M.; Askonas, B.A. Influenza nucleoprotein-specific cytotoxic t-cell clones are protective in vivo. Immunology 1986, 58, 417-420. [PubMed]

62. Sridhar, S.; Begom, S.; Bermingham, A.; Hoschler, K.; Adamson, W.; Carman, W.; Bean, T.; Barclay, W.; Deeks, J.J.; Lalvani, A. Cellular immune correlates of protection against symptomatic pandemic influenza. Nat. Med. 2013, 19, 1305-1312. [CrossRef] [PubMed]

63. Hayward, A.C.; Wang, L.; Goonetilleke, N.; Fragaszy, E.B.; Bermingham, A.; Copas, A.; Dukes, O.; Millett, E.R.; Nazareth, I.; Nguyen-Van-Tam, J.S.; et al. Natural t cell-mediated protection against seasonal and pandemic influenza. Results of the flu watch cohort study. Am. J. Respir. Crit. Care Med. 2015, 191, 1422-1431. [CrossRef] [PubMed]

64. McMichael, A.J.; Gotch, F.M.; Noble, G.R.; Beare, P.A. Cytotoxic t-cell immunity to influenza. N. Engl. J. Med. 1983, 309, 13-17. [CrossRef] [PubMed]

65. Mullarkey, C.E.; Boyd, A.; van Laarhoven, A.; Lefevre, E.A.; Veronica Carr, B.; Baratelli, M.; Molesti, E.; Temperton, N.J.; Butter, C.; Charleston, B.; et al. Improved adjuvanting of seasonal influenza vaccines: Preclinical studies of mva-np $+\mathrm{m} 1$ coadministration with inactivated influenza vaccine. Eur. J. Immunol. 2013, 43, 1940-1952. [CrossRef] [PubMed] 
66. Woodworth, J.S.; Cohen, S.B.; Moguche, A.O.; Plumlee, C.R.; Agger, E.M.; Urdahl, K.B.; Andersen, P. Subunit vaccine h56/caf01 induces a population of circulating CD4 T cells that traffic into the mycobacterium tuberculosis-infected lung. Mucosal. Immunol. 2016. [CrossRef] [PubMed]

67. Su, F.; Patel, G.B.; Hu, S.; Chen, W. Induction of mucosal immunity through systemic immunization: Phantom or reality? Hum. Vaccin Immunother. 2016, 12, 1070-1079. [CrossRef] [PubMed]

68. Ronan, E.O.; Lee, L.N.; Beverley, P.C.; Tchilian, E.Z. Immunization of mice with a recombinant adenovirus vaccine inhibits the early growth of Mycobacterium tuberculosis after infection. PLoS ONE 2009, 4, e8235. [CrossRef] [PubMed]

69. Verreck, F.A.W.; Tchilian, E.Z.; Vervenne, R.A.W.; Sombroek, C.C.; Kondova, I.; Eissen, O.A.; Sommandas, V.; van der Werff, N.M.; Verschoor, E.; Braskamp, G.; et al. Variable bcg efficacy in rhesus populations: Pulmonary bcg provides protection where standard intra-dermal vaccination fails. Tuberculosis 2017, 104, 46-57. [CrossRef] [PubMed]

70. Gutierrez, A.H.; Loving, C.; Moise, L.; Terry, F.E.; Brockmeier, S.L.; Hughes, H.R.; Martin, W.D.; De Groot, A.S. In vivo validation of predicted and conserved $\mathrm{T}$ cell epitopes in a swine influenza model. PLOS ONE 2016, 11, e0159237. [CrossRef] [PubMed]

71. Pedersen, L.E.; Breum, S.O.; Riber, U.; Larsen, L.E.; Jungersen, G. Identification of swine influenza virus epitopes and analysis of multiple specificities expressed by cytotoxic T cell subsets. Virol. J. 2014, 11, 163. [CrossRef] [PubMed]

72. Talker, S.C.; Koinig, H.C.; Stadler, M.; Graage, R.; Klingler, E.; Ladinig, A.; Mair, K.H.; Hammer, S.E.; Weissenböck, H.; Dürrwald, R.; et al. Magnitude and kinetics of multifunctional CD4+ and CD8 $\beta+$ T cells in pigs infected with swine influenza A virus. Vet. Res. 2015, 46, 52-68. [CrossRef] [PubMed]

73. Talker, S.C.; Stadler, M.; Koinig, H.C.; Mair, K.H.; Rodriguez-Gomez, I.M.; Graage, R.; Zell, R.; Durrwald, R.; Starick, E.; Harder, T.; et al. Influenza A virus infection in pigs attracts multifunctional and cross-reactive $t$ cells to the lung. J. Virol. 2016, 90, 9364-9382. [CrossRef] [PubMed]

74. Park, C.O.; Kupper, T.S. The emerging role of resident memory $\mathrm{T}$ cells in protective immunity and inflammatory disease. Nat. Med. 2015, 21, 688-697. [CrossRef] [PubMed]

75. Mueller, S.N.; Mackay, L.K. Tissue-resident memory t cells: Local specialists in immune defence. Nat. Rev. Immunol. 2016, 16, 79-89. [CrossRef] [PubMed]

76. Steinert, E.M.; Schenkel, J.M.; Fraser, K.A.; Beura, L.K.; Manlove, L.S.; Igyarto, B.Z.; Southern, P.J.; Masopust, D. Quantifying memory cd8 $\mathrm{t}$ cells reveals regionalization of immunosurveillance. Cell 2015, 161, 737-749. [CrossRef] [PubMed]

77. Wu, T.; Hu, Y.; Lee, Y.T.; Bouchard, K.R.; Benechet, A.; Khanna, K.; Cauley, L.S. Lung-resident memory CD8 $\mathrm{t}$ cells (trm) are indispensable for optimal cross-protection against pulmonary virus infection. J. Leukoc. Biol. 2014, 95, 215-224. [CrossRef] [PubMed]

78. Connor, L.M.; Harvie, M.C.; Rich, F.J.; Quinn, K.M.; Brinkmann, V.; Le Gros, G.; Kirman, J.R. A key role for lung-resident memory lymphocytes in protective immune responses after BCG vaccination. Eur. J. Immunol. 2010, 40, 2482-2492. [CrossRef] [PubMed]

79. Teijaro, J.R.; Turner, D.; Pham, Q.; Wherry, E.J.; Lefrancois, L.; Farber, D.L. Cutting edge: Tissue-retentive lung memory cd $4 \mathrm{t}$ cells mediate optimal protection to respiratory virus infection. J. Immunol. 2011, 187, 5510-5514. [CrossRef] [PubMed]

80. Turner, D.L.; Bickham, K.L.; Thome, J.J.; Kim, C.Y.; D'Ovidio, F.; Wherry, E.J.; Farber, D.L. Lung niches for the generation and maintenance of tissue-resident memory t cells. Mucosal. Immunol. 2014, 7, 501-510. [CrossRef] [PubMed]

81. de Bree, G.J.; van Leeuwen, E.M.; Out, T.A.; Jansen, H.M.; Jonkers, R.E.; van Lier, R.A. Selective accumulation of differentiated CD8+ T cells specific for respiratory viruses in the human lung. J. Exp. Med. 2005, 202, 1433-1442. [CrossRef] [PubMed]

82. Purwar, R.; Campbell, J.; Murphy, G.; Richards, W.G.; Clark, R.A.; Kupper, T.S. Resident memory T cells $(\mathrm{t}(\mathrm{rm}))$ are abundant in human lung: Diversity, function, and antigen specificity. PLoS ONE 2011, 6, e16245. [CrossRef] [PubMed]

83. Sathaliyawala, T.; Kubota, M.; Yudanin, N.; Turner, D.; Camp, P.; Thome, J.J.; Bickham, K.L.; Lerner, H.; Goldstein, M.; Sykes, M.; et al. Distribution and compartmentalization of human circulating and tissue-resident memory t cell subsets. Immunity 2013, 38, 187-197. [CrossRef] [PubMed] 
84. Jozwik, A.; Habibi, M.S.; Paras, A.; Zhu, J.; Guvenel, A.; Dhariwal, J.; Almond, M.; Wong, E.H.; Sykes, A.; Maybeno, M.; et al. Rsv-specific airway resident memory cd8+ $\mathrm{t}$ cells and differential disease severity after experimental human infection. Nat. Commun. 2015, 6, 10224. [CrossRef] [PubMed]

85. Napier, R.J.; Adams, E.J.; Gold, M.C.; Lewinsohn, D.M. The role of mucosal associated invariant T cells in antimicrobial immunity. Front. Immunol. 2015, 6, 344. [CrossRef] [PubMed]

86. Ussher, J.E.; Klenerman, P.; Willberg, C.B. Mucosal-associated invariant t-cells: New players in anti-bacterial immunity. Front. Immunol. 2014, 5, 450. [CrossRef] [PubMed]

87. Wong, E.B.; Ndung'u, T.; Kasprowicz, V.O. The role of mucosal-associated invariant T cells in infectious diseases. Immunology 2017, 150, 45-54. [CrossRef] [PubMed]

88. van Wilgenburg, B.; Scherwitzl, I.; Hutchinson, E.C.; Leng, T.Q.; Kurioka, A.; Kulicke, C.; de Lara, C.; Cole, S.; Vasanawathana, S.; Limpitikul, W.; et al. Mait cells are activated during human viral infections. Nat. Commun. 2016, 7, 11. [CrossRef] [PubMed]

89. Loh, L.; Wang, Z.F.; Sant, S.; Koutsakos, M.; Jegaskanda, S.; Corbett, A.J.; Liu, L.G.; Fairlie, D.P.; Crowe, J.; Rossjohn, J.; et al. Human mucosal-associated invariant t cells contribute to antiviral influenza immunity via Il-18-dependent activation. Proc. Natl. Acad. Sci. USA 2016, 113, 10133-10138. [CrossRef] [PubMed]

90. Corti, D.; Suguitan, A.L., Jr.; Pinna, D.; Silacci, C.; Fernandez-Rodriguez, B.M.; Vanzetta, F.; Santos, C.; Luke, C.J.; Torres-Velez, F.J.; Temperton, N.J.; et al. Heterosubtypic neutralizing antibodies are produced by individuals immunized with a seasonal influenza vaccine. J. Clin. Invest. 2010, 120, 1663-1673. [CrossRef] [PubMed]

91. Sui, J.; Hwang, W.C.; Perez, S.; Wei, G.; Aird, D.; Chen, L.M.; Santelli, E.; Stec, B.; Cadwell, G.; Ali, M.; et al. Structural and functional bases for broad-spectrum neutralization of avian and human influenza a viruses. Nat. Struct. Mol. Biol. 2009, 16, 265-273. [CrossRef] [PubMed]

92. Throsby, M.; van den Brink, E.; Jongeneelen, M.; Poon, L.L.; Alard, P.; Cornelissen, L.; Bakker, A.; Cox, F.; van Deventer, E.; Guan, Y.; et al. Heterosubtypic neutralizing monoclonal antibodies cross-protective against h5n1 and H1N1 recovered from human igm+ memory b cells. PLoS ONE 2008, 3, e3942. [CrossRef] [PubMed]

93. Henry Dunand, C.J.; Leon, P.E.; Kaur, K.; Tan, G.S.; Zheng, N.Y.; Andrews, S.; Huang, M.; Qu, X.; Huang, Y.; Salgado-Ferrer, M.; et al. Preexisting human antibodies neutralize recently emerged H7N9 influenza strains. J. Clin. Invest. 2015, 125, 1255-1268. [CrossRef] [PubMed]

94. Ekiert, D.C.; Friesen, R.H.; Bhabha, G.; Kwaks, T.; Jongeneelen, M.; Yu, W.; Ophorst, C.; Cox, F.; Korse, H.J.; Brandenburg, B.; et al. A highly conserved neutralizing epitope on group 2 influenza a viruses. Science 2011, 333, 843-850. [CrossRef] [PubMed]

95. Friesen, R.H.; Lee, P.S.; Stoop, E.J.; Hoffman, R.M.; Ekiert, D.C.; Bhabha, G.; Yu, W.; Juraszek, J.; Koudstaal, W.; Jongeneelen, M.; et al. A common solution to group 2 influenza virus neutralization. Proc. Natl. Acad. Sci. USA 2014, 111, 445-450. [CrossRef] [PubMed]

96. Corti, D.; Voss, J.; Gamblin, S.J.; Codoni, G.; Macagno, A.; Jarrossay, D.; Vachieri, S.G.; Pinna, D.; Minola, A.; Vanzetta, F.; et al. A neutralizing antibody selected from plasma cells that binds to group 1 and group 2 influenza a hemagglutinins. Science 2011, 333, 850-856. [CrossRef] [PubMed]

97. Dreyfus, C.; Laursen, N.S.; Kwaks, T.; Zuijdgeest, D.; Khayat, R.; Ekiert, D.C.; Lee, J.H.; Metlagel, Z.; Bujny, M.V.; Jongeneelen, M.; et al. Highly conserved protective epitopes on influenza b viruses. Science 2012, 337, 1343-1348. [CrossRef] [PubMed]

98. Nakamura, G.; Chai, N.; Park, S.; Chiang, N.; Lin, Z.; Chiu, H.; Fong, R.; Yan, D.; Kim, J.; Zhang, J.; et al. An in vivo human-plasmablast enrichment technique allows rapid identification of therapeutic influenza A antibodies. Cell Host Microbe 2013, 14, 93-103. [CrossRef] [PubMed]

99. Wu, Y.; Cho, M.; Shore, D.; Song, M.; Choi, J.; Jiang, T.; Deng, Y.Q.; Bourgeois, M.; Almli, L.; Yang, H.; et al. A potent broad-spectrum protective human monoclonal antibody crosslinking two haemagglutinin monomers of influenza a virus. Nat. Commun. 2015, 6, 7708. [CrossRef] [PubMed]

100. Kallewaard, N.L.; Corti, D.; Collins, P.J.; Neu, U.; McAuliffe, J.M.; Benjamin, E.; Wachter-Rosati, L.; Palmer-Hill, F.J.; Yuan, A.Q.; Walker, P.A.; et al. Structure and function analysis of an antibody recognizing all influenza a subtypes. Cell 2016, 166, 596-608. [CrossRef] [PubMed]

101. Cho, A.; Wrammert, J. Implications of broadly neutralizing antibodies in the development of a universal influenza vaccine. Curr. Opin. Virol. 2016, 17, 110-115. [CrossRef] [PubMed]

102. Krammer, F. Novel universal influenza virus vaccine approaches. Curr. Opin. Virol. 2016, 17, 95-103. [CrossRef] [PubMed] 
103. Adachi, Y.; Onodera, T.; Yamada, Y.; Daio, R.; Tsuiji, M.; Inoue, T.; Kobayashi, K.; Kurosaki, T.; Ato, M.; Takahashi, Y. Distinct germinal center selection at local sites shapes memory b cell response to viral escape. J. Exp. Med. 2015, 212, 1709-1723. [CrossRef] [PubMed]

104. Renegar, K.B.; Small, P.A.; Boykins, L.G.; Wright, P.F. Role of iga versus igg in the control of influenza viral infection in the murine respiratory tract. J. Immunol. 2004, 173, 1978-1986. [CrossRef] [PubMed]

105. Taylor, H.P.; Dimmock, N.J. Mechanism of neutralization of influenza virus by secretory IGA is different from that of monomeric iga or igg. J. Exp. Med. 1985, 161, 198-209. [CrossRef] [PubMed]

106. Suzuki, T.; Kawaguchi, A.; Ainai, A.; Tamura, S.; Ito, R.; Multihartina, P.; Setiawaty, V.; Pangesti, K.N.; Odagiri, T.; Tashiro, M.; et al. Relationship of the quaternary structure of human secretory IGA to neutralization of influenza virus. Proc. Natl. Acad. Sci. USA 2015, 112, 7809-7814. [CrossRef] [PubMed]

107. Mazanec, M.B.; Coudret, C.L.; Fletcher, D.R. Intracellular neutralization of influenza virus by immunoglobulin a anti-hemagglutinin monoclonal antibodies. J. Virol. 1995, 69, 1339-1343. [PubMed]

108. Lee, B.W.; Bey, R.F.; Baarsch, M.J.; Larson, M.E. Class specific antibody response to influenza a H1N1 infection in swine. Vet. Microbiol. 1995, 43, 241-250. [CrossRef]

109. Larsen, D.L.; Karasin, A.; Zuckermann, F.; Olsen, C.W. Systemic and mucosal immune responses to H1N1 influenza virus infection in pigs. Vet. Microbiol. 2000, 74, 117-131. [CrossRef]

110. Jones, P.D.; Ada, G.L. Influenza-specific antibody-secreting cells and b cell memory in the murine lung after immunization with wild-type, cold-adapted variant and inactivated influenza viruses. Vaccine 1987, 5, 244-248. [CrossRef]

111. Nachbagauer, R.; Choi, A.; Hirsh, A.; Margine, I.; Iida, S.; Barrera, A.; Ferres, M.; Albrecht, R.A.; Garcia-Sastre, A.; Bouvier, N.M.; et al. Defining the antibody cross-reactome directed against the influenza virus surface glycoproteins. Nat. Immunol. 2017, 18, 464-473. [CrossRef] [PubMed]

112. Epstein, S.L. Prior H1N1 influenza infection and susceptibility of cleveland family study participants during the h2n2 pandemic of 1957: An experiment of nature. J. Infect. Dis. 2006, 193, 49-53. [CrossRef] [PubMed]

113. Gostic, K.M.; Ambrose, M.; Worobey, M.; Lloyd-Smith, J.O. Potent protection against H5N1 and H7N9 influenza via childhood hemagglutinin imprinting. Science 2016, 354, 722-726. [CrossRef] [PubMed]

114. Khurana, S.; Loving, C.L.; Manischewitz, J.; King, L.R.; Gauger, P.C.; Henningson, J.; Vincent, A.L.; Golding, H. Vaccine-induced anti-HA2 antibodies promote virus fusion and enhance influenza virus respiratory disease. Sci. Transl. Med. 2013, 5, 200ra114. [CrossRef] [PubMed]

115. Gauger, P.C.; Loving, C.L.; Khurana, S.; Lorusso, A.; Perez, D.R.; Kehrli, M.E.; Roth, J.A.; Golding, H.; Vincent, A.L. Live attenuated influenza a virus vaccine protects against a (H1N1) pdm09 heterologous challenge without vaccine associated enhanced respiratory disease. Virology 2014, 471-473, 93-104. [CrossRef] [PubMed]

116. Rajao, D.S.; Loving, C.L.; Gauger, P.C.; Kitikoon, P.; Vincent, A.L. Influenza a virus hemagglutinin protein subunit vaccine elicits vaccine-associated enhanced respiratory disease in pigs. Vaccine 2014, 32, 5170-5176. [CrossRef] [PubMed]

117. Rajao, D.S.; Chen, H.; Perez, D.R.; Sandbulte, M.R.; Gauger, P.C.; Loving, C.L.; Shanks, G.D.; Vincent, A. Vaccine-associated enhanced respiratory disease is influenced by haemagglutinin and neuraminidase in whole inactivated influenza virus vaccines. J. Gen. Virol. 2016, 97, 1489-1499. [PubMed]

(C) 2017 by the authors. Licensee MDPI, Basel, Switzerland. This article is an open access article distributed under the terms and conditions of the Creative Commons Attribution (CC BY) license (http://creativecommons.org/licenses/by/4.0/). 